\title{
STUDI PENCAMPURAN SERAT ECENG GONDOK PADA CAMPURAN BETON DENGAN PENGGUNAAN AGREGAT KASAR DARI KECAMATAN MANTUP
}

\author{
Kartisyah Wulandari ${ }^{1}$; Dwi Kartikasari ${ }^{2}$ \\ ${ }^{1,2}$ Fakultas Teknik Universitas Islam Lamongan \\ email : kartisyahwulandari@yahoo.com; dkartika27@gmail.com
}

\begin{abstract}
The purpose of this study is to know the characteristics of coarse aggregate of Mantup and to determine the effect of natural water hyacinth fiber addition from the using of coarse aggregate of Mantup towards the concrete compressive strength. This research method employs experimental method with mix design reference of SNI 03-2834-2000. To determine the effect of adding the natural water hyacinth fiber and coarse aggregate of Mantup, the experiment is done with the variation of $0 \%, 4 \%, 6 \%$, and $8 \%$ by weight of the cement. The test object used is cylinders $\varnothing 15 \mathrm{~cm} \times 30 \mathrm{~cm}$. The number of samples made as many as 12 samples, consisting of 4 variations and for each variation is made 3 samples. After doing the immersion for 7 days, it is done the testing that can be conversed to 28 days. From the test, obtained the result that the compressive strength for the $0 \%$ fiber variation produces compressive strength of $94,36 \mathrm{~kg} / \mathrm{cm}^{2}$, for $4 \%$ fiber variation produces compressive strength of $40.44 \mathrm{~kg} / \mathrm{cm}^{2}$, for $6 \%$ fiber variation produces compressive strength of $48.53 \mathrm{~kg} / \mathrm{cm}^{2}$, and for the $8 \%$ fiber variation produces compressive strength of $47.18 \mathrm{~kg} / \mathrm{cm}^{2}$.
\end{abstract}

Keywords : Water Hyacinth, Coarse Aggregate of Mantup, Compressive Strength of Concrete 1.

\begin{abstract}
ABSTRAK
Tujuan dari penelitian ini adalah untuk mengetahui karakteristik agregat kasar Mantup dan untuk mengetahui pengaruh penambahan serat eceng gondok dari penggunaan agregat kasar Mantup terhadap kekuatan tekan beton. Metode penelitian ini menggunakan metode eksperimental dengan rujukan desain campuran SNI 03-2834-2000. Untuk mengetahui pengaruh penambahan serat eceng gondok air dan agregat kasar Mantup, percobaan dilakukan dengan variasi $0 \%, 4 \%, 6 \%$, dan $8 \%$ berat semen. Objek uji yang digunakan adalah silinder $\varnothing 15 \mathrm{~cm} \times 30 \mathrm{~cm}$. Jumlah sampel yang dibuat sebanyak 12 sampel, terdiri dari 4 variasi dan untuk setiap variasi dibuat 3 sampel. Setelah melakukan perendaman selama 7 hari, dilakukan pengujian yang dapat dikonversi menjadi 28 hari. Dari pengujian, diperoleh hasil bahwa kuat tekan untuk variasi serat 0\% menghasilkan kuat tekan 94,36kg / $\mathrm{cm}^{2}$, untuk variasi serat $4 \%$ menghasilkan kuat tekan $40,44 \mathrm{~kg} / \mathrm{cm}^{2}$, untuk variasi serat $6 \%$ menghasilkan kuat tekan $48,53 \mathrm{~kg} / \mathrm{cm}^{2}$, dan untuk variasi serat $8 \%$ menghasilkan kuat tekan $47,18 \mathrm{~kg}$ / $\mathrm{cm}^{2}$.
\end{abstract}

Kata Kunci: Hyacinth Air, Agregat kasar Mantup, Kekuatan Tekan Beton 1

\section{PENDAHULUAN}

Kata beton dalam bahasa inggris berasal dari bahasa Latin concretus yang berarti tumbuh bersama atau menggabungkan menjadi satu. Dalam bahasa Jepang digunakan kata kotau-zai, yang arti harafiahnya material-material seperti tulang; mungkin karena agregat mirip tulang- 
tulang hewan. (Tjokrodimulyo, 2007) Beton merupakan pencampuran dari semen, agregat halus, agregat kasar dan air dengan suatu perbandingan tertentu. Jika ingin membuat beton berkualitas baik, dalam arti memenuhi persyaratan yang lebih ketat karena tuntutan yang lebih tinggi, maka harus diperhitungkan dengan seksama cara-cara memperoleh adukan beton(beton segar/fresh concrete) yang baik dan beton (beton keras / hardened concrete) yang dihasilkan juga baik. Beton yang baik ialah beton yang kuat, tahan lama/awet, kedap air, tahan aus, dan sedikit mengalami perubahan volume (kembang susutnya kecil). Dari penelitihan terdahulu ternyata eceng gondong ini memiliki kandungan senyawa kimia yang sangat berperan penting dalam pembuatan semen, Penggunaan bahan tambahan kimia sesuai kebutuhan untuk memperkuat hasil beton pun dilakukan demi menghasilhan beton yang berkualitas baik. Eceng gondok dimanfaatkan untuk dibuat serbuk yang akan digunakan sebagai campuran pembuatan beton (Hidayat,2011). Tujuan Penelitian ini adalah Untuk mengetahui fungsi dan pembuatan eceng gondok sebagai bahan serat selulosa yang digunakan sebagai bahan tambah untuk meningkatkan kuat tekan beton.

\section{METODE PENELITIAN}

Penelitian ini menggunakan metode penelitian eksperimental laboratorium yaitu mengadakan kegiatan percobaan untuk mengadakan suatu hasil. Tujuan eksperimen ini yaitu untuk membandingkan hasil yang telah didapat dalam penelitian dengan syarat - syarat yang ada. Waktu dan tempat penelitian ini akan dilakukan di Laboratorium Teknik Sipil Universitas Islam Lamongan Jl. Veteran No.53 A Lamongan. Penelitian ini dilakukan mulai bulan Februari 2018 sampai selesai.

\subsection{Pelaksanaan Penelitian}

Bahan

Bahan - bahan yang digunakan dalam pembuatan benda uji adalah:

a. Semen Portland

b. Agregat Kasar (Kerikil)

c. Agregat Halus (Pasir)

d. Serat Alami Eceng gondok e. Air

Peralatan

Peralatan yang dibutuhkan dalam penelitian ini adalah :

a. Alat pencampur bahan :

- Concrete mixer 
- Sekop /sendok semen

b. Cetakan silinder beton

c. Mesin tekan hidrolis untuk menguji kuat tekan beton

\subsection{Pengujian Bahan Susun Campuran Beton}

Pada tahap ini dilakukan dan pemeriksaan bahan penelitian yaitu Semen, Agregat, Serat Eceng gondok dan Beton. Pemeriksaan dilakukan untuk mengetahui sifat - sifat bahan apakah memenuhi standart spesifikasi yang telah di tentukan. Pengujian bahan susun campuran beton dengan menggunakan standar yang telah ditetapkan dan berlaku di Indonesia terdiri dari :

a) Penyelidikan Bahan Semen :

1. Percobaan Konsistensi Normal Semen (ASTM C 187-86)

2. Percobaan Berat Jenis Semen (ASTM C 188-89)

3. Percobaan Waktu Mengikat dan Mengeras Semen (ASTM 119-92)

b) Penyelidikan Bahan Pasir :

1. Pengujian Kadar Air Agregat (ASTM C 556 - 89)

2. Percobaan Berat Jenis Pasir (ASTM C 128-93)

3. Percobaan Air Resapan Pasir (ASTM C 128-93)

4. Percobaan Bobot Isi dan Rongga Udara (ASTM C 188-89)

5. Percobaan Analisa Saringan Pasir (ASTM C 136-95a)

c) Penyelidikan Bahan Batu Pecah

1. Percobaan Kelembapan Batu Pecah (ASTM C 566-89)

2. Percobaan Berat Jenis Batu Pecah (ASTM C 127-88-93)

3. Percobaan Air Resapan Batu Pecah (ASTM C 127-88-93)

4. Percobaan Berat Volume Batu Pecah (ASTM C 29-91)

5. Percobaan Analisa Saringan Batu Pecah (ASTM C 136-95a)

d) Pemeriksaan Serat Eceng gondok

Serat eceng gondok yang digunakan adalah eceng gondok yang diproses sendiri oleh peneliti sehingga menjadi serat eceng gondok yang dibutuhkan.

\subsection{Tahap Pembuatan Serat dari Enceng Gondok}

1. Pengambilan enceng gondok dari daerah sungai di Kecamatan Deket Kabupaten Lamongan.

2. Pembersihan enceng gondok dengan air bersih.

3. Eceng gondok dipotong-potong antara $5-10 \mathrm{~cm}$

4. Setelah enceng gondok dipotong-potong kemudian eceng gondok di gilingkan di tempat penggilingan. 
5. Selesai digilingkan, kemudian serat eceng gondok dijemur sampai benar-benar kering. Variasi penambahan serat eceng gondok yang digunakan sebesar $0 \%, 1 \%, 3 \%$ dan $5 \%$ dari berat semen. Kemudian pembuatan benda uji dan penambahan serat eceng gondok pada masing - masing variasi dilakukan 3 kali sesuai dengan umur beton. Setiap pengujian terdapat 3 benda uji untuk setiap varian.

\subsection{Proses Perawatan Beton}

1. Setelah 24 jam dari proses pencetakan beton, cetakan beton dibuka perlahan-lahan dan benda uji silinder beton diambil

2. Benda uji kubus beton diletakkan dalam suatu bak air, dan dibiarkan sampai sehari sebelum waktu pengetesan untuk dikeluarkan dari bak (pengeringan)

3. Pada waktu pengetesan, benda uji yang telah dikeluarkan dari bak dan mengering ditimbang beratnya setelah itu diukur dimensinya

4. Kemudian benda uji dicapping / diratakan dengan larutan belerang pada bidang tidak rata

5. Permukaan yang dicapping dari benda uji diletakkan di atas, dan benda uji siap dites Langkah tersebut berlaku untuk benda uji yang berumur 7 hari.

\section{HASIL DAN PEMBAHASAN}

Berdasarkan metode pengujian referensi standart yang berlaku, penulis melakukan pengujian di Laboratorium Universitas Islam Lamongan (UNISLA). Pengujian karakteristik material halus dan kasar merupakan pengujian awal yang di lakukan agar mengetahui karakteristik agregat halus dan kasar sebelum melakukan mix design beton yang mengacu pada SNI.

Dari data yang telah diperoleh selama pengujian, maka dilakukan perencanaan rancang campur (Mix Design SNI 03-2834-2000) pada beton dengan memanfaatkan serat alami eceng gondok, dalam pengujian tersebut beton merujuk pada beton mutu sedang dengan prosentase bervariasi pada komposisi semen yang dikurangi oleh serat alami eceng gondok. Benda uji yang digunakan adalah silinder dengan ukuran tinggi $30 \mathrm{~cm}$ dan diameter $15 \mathrm{~cm}$ sebanyak 3 buah untuk setiap sample campuran beton untuk diujikan kuat tekan beton pada umur 7 hari. Diharapkan dari hasil penelitian ini, peneliti dapat mengetahui hasil kuat tekan beton

\subsection{Pencampuran Beton Segar (Mix Design) Data Perencanaan}

1. Deviasi standart : : Beton Non Struktural

2. Jenis semen : Semen portland

3. Jenis serat $\quad$ : Serat alami eceng gondok

4. Jenis agregat kasar : Agregat kasar Mantup 
5. Jenis agregat halus : Pasir

6. Mutu beton : Beton Non Struktural

7. Umur perawatan : 7 hari

8. Jenis benda uji : Silinder

Diketahui - Tinggi silinder $=30 \mathrm{~cm}$

- Diameter silinder $=15 \mathrm{~cm}(\mathrm{r}=7,5 \mathrm{~cm})$ Maka

Volume silinder

$$
\begin{aligned}
& =\pi \times \mathrm{r}^{2} \times \mathrm{t} \\
& =3,14 \times 7,5^{2} \times 30 \\
& =529,75 \mathrm{~cm}^{2} \\
& =5299 \times 10^{3} \mathrm{x} \mathrm{m}^{3} \\
& =0.0053 \mathrm{~m}^{3}
\end{aligned}
$$

\begin{tabular}{|c|c|c|c|c|}
\hline No & $\begin{array}{l}\text { Uraian } \\
\text { Kegiatan }\end{array}$ & $\begin{array}{l}\text { Kajian } \\
\text { Puntalcal } \\
\text { Laudasan } \\
\text { Teori }\end{array}$ & $\begin{array}{l}\text { Hasil } \\
\text { Penelitian }\end{array}$ & Ket. \\
\hline$I_{1}$ & $\begin{array}{l}\text { Kosistani } \\
\text { Normal } \\
\text { Sernen } \\
\text { Portland }\end{array}$ & $\begin{array}{l}\text { Berdaarka } \\
\text { (ASDMC } \\
187-86) \\
\text { adalah } 26-29 \\
\text { y pada } \\
\text { penunum } 10 \\
\text { Inm }\end{array}$ & $\begin{array}{l}\text { Didapatan } \\
\text { nilai } \\
\text { sebesar } \\
28 \% \text { paita } \\
\text { penunuman } \\
10 \text { min }\end{array}$ & Merrenulh: \\
\hline 2 & $\begin{array}{l}\text { Pengujian } \\
\text { Berat Jenis } \\
\text { Senen }\end{array}$ & $\begin{array}{l}\text { Berdasarlan } \\
\text { ASM } 188 \text { - } \\
89 \text { adalah } \\
\text { mempunya } \\
\text { kisaran } 30- \\
32 \text { tim }^{\prime}\end{array}$ & $\begin{array}{l}\text { Didapatan } \\
\text { nilai rat } \\
\text { rata sebesi } \\
3,13 \text { t/m'. }\end{array}$ & Merrenuhi \\
\hline
\end{tabular}

\subsection{Analisa Bahan Semen}

Tabel 1: Kesesuaian Hasil Penelitian Analisa

Sumber : Hasil penelitian, 2018

Berdasarkan tabel 1 diatas diketahui bahwa kedua pengujian bahan semen memenuhi standart. 


\subsection{Analisa Bahan Agregat Halus}

Tabel 2: Kesesuaian Hasil Penelitian Agregat Halus

\begin{tabular}{|c|c|c|c|c|}
\hline No & $\begin{array}{l}\text { Uraian } \\
\text { Kegiatan }\end{array}$ & $\begin{array}{l}\text { Kajian } \\
\text { Puataka/ } \\
\text { Landasan } \\
\text { Tani }\end{array}$ & $\begin{array}{l}\text { Hasil } \\
\text { Penelitian }\end{array}$ & Ket. \\
\hline 1. & $\begin{array}{l}\text { Pengujian } \\
\text { Ayalian } \\
\text { Agregat } \\
\text { Halus }\end{array}$ & $\begin{array}{l}\text { Berdaarkan } \\
\text { ASTM C } \\
33-78 \text { Nilai } \\
\text { adalah } 2,2- \\
3,1\end{array}$ & $\begin{array}{l}\text { Didapathan } \\
\text { nilai sebagar } \\
3,42\end{array}$ & $\begin{array}{l}\text { Tidal: } \\
\text { Memeru } \\
\text { hi }\end{array}$ \\
\hline 2. & $\begin{array}{l}\text { Pengujian } \\
\text { Kelembapan } \\
\text { Agregat } \\
\text { Halus }\end{array}$ & $\begin{array}{l}\text { Berdaarkan } \\
\text { ASTM C } \\
566-89 \\
\text { kelembapan } \\
\text { pasir c0,1\% }\end{array}$ & $\begin{array}{l}\text { kelembapan } \\
\text { agregat } \\
\text { halus } \\
\text { didspathan } \\
\text { nilai rata- } \\
\text { rata gabear } \\
0,06\end{array}$ & $\begin{array}{l}\text { Memenu } \\
\text { hi }\end{array}$ \\
\hline 3. & $\begin{array}{l}\text { Pengujian } \\
\text { Berai Jenis } \\
\text { Agregat } \\
\text { Halus }\end{array}$ & $\begin{array}{l}\text { Berdaarhan } \\
\text { ASTM C } \\
128-78 \\
\text { adalah } \\
2,4-2,7 \\
\text { gridm? }\end{array}$ & $\begin{array}{l}\text { didapathan } \\
\text { rilai rata- } \\
\text { rata abear } \\
2,40 \text { gr/dm". }\end{array}$ & $\begin{array}{l}\text { Mement } \\
\text { hi }\end{array}$ \\
\hline 4. & $\begin{array}{l}\text { Pangujian } \\
\text { Air Reapan } \\
\text { Agregat } \\
\text { Halus }\end{array}$ & $\begin{array}{l}\text { Berdaarinan } \\
\text { ASTM C } \\
128-93 \\
\text { adalah } 1-4 \%\end{array}$ & $\begin{array}{l}\text { didapatlar } \\
\text { rilai sebear } \\
1,10 \% \text {. }\end{array}$ & $\begin{array}{l}\text { Mement } \\
\text { hi }\end{array}$ \\
\hline 5. & $\begin{array}{l}\text { Pengujian } \\
\text { Berai } \\
\text { Volume } \\
\text { Agregat } \\
\text { Halus }\end{array}$ & $\begin{array}{l}\text { Berdaarlan } \\
\text { ASTM C } \\
29 \mathrm{M}-91 \\
\text { adalah } 1,25 \\
-1,59 \mathrm{~kg} / \mathrm{tt} .\end{array}$ & $\begin{array}{l}\text { Didapathan } \\
\text { rilai gebesar } \\
1,3 \mathrm{~kg} / \mathrm{lt} .\end{array}$ & $\begin{array}{l}\text { Mement } \\
\text { hi }\end{array}$ \\
\hline
\end{tabular}

Sumber : Hasil penelitian, 2018

Berdasarkan tabel 2 diketahui bahwa pengujian ayakan agregat halus yang tidak memenuhi standart. pada pengujian kelembapan agregat halus memenuhi standart. pada pengujian berat jenis agregat halus memenuhi standart. pada pengujian air resapan agregat halus memenuhi standart. pada pengujian berat volume agregat halus memenuhi standart.

\subsection{Analisa Bahan Agregat Kasar Mantup}

Tabel 3: Kesesuaian Hasil Penelitian Agregat Kasar Mantup 


\begin{tabular}{|c|c|c|c|c|}
\hline No & $\begin{array}{l}\text { Uraian } \\
\text { Todiatan }\end{array}$ & $\begin{array}{l}\text { Kaiian } \\
\text { Dwatalof } \\
\text { Tamflowan } \\
\text { Tani }\end{array}$ & $\begin{array}{l}\text { Hasil } \\
\text { Dowalition }\end{array}$ & Ket. \\
\hline 1 & $\begin{array}{l}\text { Donpritian } \\
\text { Avalisan } \\
\text { Asragat } \\
\text { Kasar } \\
\text { Mrantim }\end{array}$ & 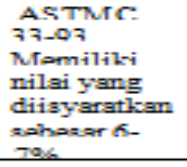 & $\begin{array}{l}\text { Diclamatlsan } \\
\text { nilsi saheser } \\
420\end{array}$ & $\begin{array}{l}\text { Ticial- } \\
\text { Nreme } \\
\text { nnhi }\end{array}$ \\
\hline 2. & $\begin{array}{l}\text { Pengujian } \\
\text { Kelomhama } \\
\text { n Agregat } \\
\text { Kasar } \\
\text { Mrantup }\end{array}$ & $\begin{array}{l}\text { Kelembapa } \\
\text { n agregat } \\
\text { lcasar } \\
\text { berdiasarkan } \\
\text { A STM C } \\
566-89 \\
\text { arialah } 0 \text { - } \\
3 \%\end{array}$ & $\begin{array}{l}\text { Didapatkan } \\
\text { rata-rata } \\
\text { sebeasar } 4,18 \\
96\end{array}$ & $\begin{array}{l}\text { Tidel } \\
\text { Mrome } \\
\text { nuhi }\end{array}$ \\
\hline 3. & $\begin{array}{l}\text { Pengujian } \\
\text { Berat Jenis } \\
\text { Agregat } \\
\text { Kasar } \\
\text { Mantup }\end{array}$ & $\begin{array}{l}\text { Berdasarka } \\
\text { n A T TMI C } \\
128-78 \\
\text { adialah } 2,2 \\
\text { gram } 1 t-2,7 \\
\text { gram } 11 . \\
\end{array}$ & $\begin{array}{l}\text { Didapatkan } \\
\text { nilai rata-rata } \\
\text { aebeasar } 4,37 \\
\text { gram / } \text { dim }^{3} \text {. }\end{array}$ & $\begin{array}{l}\text { Tidalk } \\
\text { Merme } \\
\text { nuhi }\end{array}$ \\
\hline 4. & $\begin{array}{l}\text { Pengujian } \\
\text { Air } \\
\text { Resapan } \\
\text { A } \\
\text { Kasar } \\
\text { MIantup }\end{array}$ & $\begin{array}{l}\text { berdaaarkan } \\
\text { ASTMI C } \\
127-88-93 \\
\text { adialah } 1- \\
496\end{array}$ & $\begin{array}{l}\text { Didapatlsan } \\
\text { nilai rata-rata } \\
\text { aebeasar } 5,25 \\
\text { a. }\end{array}$ & $\begin{array}{l}\text { Tidiak } \\
\text { Meme } \\
\text { nuhi }\end{array}$ \\
\hline 5. & $\begin{array}{l}\text { Pengujian } \\
\text { Berat } \\
\text { Volume } \\
\text { Kaasr } \\
\text { MIantup } \\
\end{array}$ & $\begin{array}{l}\text { Berdasarka } \\
\text { n ASTMI C } \\
29-91 \\
\text { adalah } 1,4 \\
\text { kg/lt }-1.7 \\
\text { kg/lt }\end{array}$ & $\begin{array}{l}\text { Didapatkan } \\
\text { nilai aebesar } \\
1,4 \mathrm{~kg} / \mathrm{tt}\end{array}$ & $\begin{array}{l}\text { Nome } \\
\text { nuhi }\end{array}$ \\
\hline
\end{tabular}

Sumber : Hasil penelitian, 2018

Dari tabel 4 diatas dapat diketahui bahwa dalam pengujian pada pengujian ayakan agregat kasar mantup tidak memenuhi standar. Pada pengujian kelembapan agregat mantup tidak memenuhi standar. Pada pengujian berat jenis agregat Mantup tidak memenuhi standar. Pada pengujian air resapan agregat Mantup tidak memenuhi standar. Pada pengujian beat volume agregat Mantup memenuh standar.

\subsection{Analisa Kuat Tekan Beton}

Tabel 4: Pengujian Kuat Tekan Beton Silinder Umur 7. Hari

\begin{tabular}{|c|c|c|c|c|}
\hline $\begin{array}{c}\text { No } \\
\text { Benda } \\
\text { Uji }\end{array}$ & $\begin{array}{l}96 \text { Serat } \\
\text { Eceng } \\
\text { Gond ol }\end{array}$ & $\begin{array}{c}\text { Telcanan } \\
\text { Hancur } \\
\text { (lkg) }\end{array}$ & $\begin{array}{c}\text { Tegangan } \\
\text { Hancur } \\
\text { Umur } 7 \\
\text { Hari } \\
\left(\mathrm{kg} / \mathrm{cm}^{2}\right)\end{array}$ & $\begin{array}{c}\text { Rata- } \\
\text { Rata } \\
\text { Tegangan } \\
\text { Hancur } \\
\text { Umur } 7 \\
\text { Hari } \\
\left(\mathrm{kg} / \mathrm{cm}^{2}\right)\end{array}$ \\
\hline $\begin{array}{l}1 . \\
2 . \\
3 .\end{array}$ & $\begin{array}{l}\text { Serat } \\
\text { Eceng } \\
\text { Gonaok }\end{array}$ & $\begin{array}{r}11500 \\
12000 \\
11500 \\
0 \%\end{array}$ & $\begin{array}{l}65,11 \\
67,94 \\
05,11\end{array}$ & 66,05 \\
\hline $\begin{array}{l}4 . \\
5 . \\
6 .\end{array}$ & $\begin{array}{l}\text { Serat } \\
\text { Eceng } \\
\text { Gondol } \\
4 \%\end{array}$ & $\begin{array}{l}5000 \\
5000 \\
5000\end{array}$ & $\begin{array}{l}28,31 \\
28,31 \\
28,31\end{array}$ & 28,31 \\
\hline $\begin{array}{l}7 . \\
8 . \\
9 .\end{array}$ & $\begin{array}{l}\text { Serat } \\
\text { Eceng } \\
\text { Gondok } \\
\text { oro }\end{array}$ & $\begin{array}{l}6000 \\
6000 \\
6000\end{array}$ & $\begin{array}{l}33,97 \\
33,97 \\
33,97\end{array}$ & 33,97 \\
\hline $\begin{array}{l}10 . \\
11 . \\
12 .\end{array}$ & $\begin{array}{l}\text { Serat } \\
\text { Eceng } \\
\text { Gondol } \\
8 \%\end{array}$ & $\begin{array}{l}5500 \\
6000 \\
6000\end{array}$ & $\begin{array}{l}31,14 \\
33,97 \\
33,97\end{array}$ & 33,03 \\
\hline
\end{tabular}

Sumber : Hasil penelitian, 2018

Tabel 5: Pengujian Kuat Beton Silinder Umur28 Hari (Dikorelasi) 


\begin{tabular}{|c|c|c|c|c|}
\hline $\begin{array}{l}\text { No } \\
\text { Benda } \\
\text { Uji }\end{array}$ & $\begin{array}{l}\text { 96 Serat } \\
\text { Eceng } \\
\text { Gondol }\end{array}$ & $\begin{array}{l}\text { Tekanan } \\
\text { Hancur } \\
\text { (kg) }\end{array}$ & $\begin{array}{l}\text { Tegangan } \\
\text { Hancur } \\
\text { Umur 28 } \\
\text { Hari } \\
\left(\mathrm{kg} / \mathrm{cm}^{2}\right)\end{array}$ & $\begin{array}{l}\text { Rata- } \\
\text { Rata } \\
\text { Tegangan } \\
\text { Hancur } \\
\text { Umur 28 } \\
\text { Hari } \\
\left(\mathrm{kg} / \mathrm{cm}^{2}\right)\end{array}$ \\
\hline \multirow{3}{*}{$\begin{array}{l}1 . \\
2 . \\
5 .\end{array}$} & Serat & 11500 & 93,01 & \multirow{3}{*}{94,36} \\
\hline & Eceng & 12000 & 97,06 & \\
\hline & $0 \%$ & t+ave & $\Rightarrow \nu, \mathrm{vL}$ & \\
\hline \multirow{3}{*}{$\begin{array}{l}4 \\
5 . \\
6 .\end{array}$} & \multirow{3}{*}{$\begin{array}{l}\text { Serat } \\
\text { Eceng } \\
\text { Gondol } \\
4 \% \\
\end{array}$} & 5000 & 40,44 & \multirow{3}{*}{40,44} \\
\hline & & 5000 & 40,44 & \\
\hline & & 5000 & 40,44 & \\
\hline \multirow{3}{*}{$\begin{array}{l}\text { s. } \\
8 .\end{array}$} & \multirow{3}{*}{$\begin{array}{l}\text { Gondok } \\
6 \%\end{array}$} & vons & ענגטד & \multirow{3}{*}{48,53} \\
\hline & & 6000 & 48,53 & \\
\hline & & 6000 & 48,53 & \\
\hline \multirow{2}{*}{$\begin{array}{l}10 . \\
11 .\end{array}$} & Serat & 5500 & 44,48 & \multirow{3}{*}{47,18} \\
\hline & $\begin{array}{l}\text { Eceng } \\
\text { Gondol: }\end{array}$ & 6000 & 48,53 & \\
\hline 12. & $8 \%$ & 6000 & 48,53 & \\
\hline
\end{tabular}

Sumber : Hasil penelitian, 2018

Dari tabel 4 dan 5 diatas dapat diketahui untuk kuat tekan beton normal memiliki niali rata-rata sebesar $66,05 \mathrm{~kg} / \mathrm{cm}^{2}$ pada umur 7 haridan sebesar $94,36 \mathrm{~kg} / \mathrm{cm}^{2}$ pada umur 28 hari. Pada beton dengan penambahan serat eceng gondok sebesar $4 \%$ memiliki nilai kuat tekan rata-rata sebesar $28,31 \mathrm{~kg} / \mathrm{cm}^{2}$ pada umur 7 hari dan sebesar $40,44 \mathrm{~kg} / \mathrm{cm}^{2}$ pada umur 28 hari. Pada beton dengan penambahan serat eceng gondok sebesar $6 \%$ memiliki nilai kuat tekan rata-rata sebesar 33,97 $\mathrm{kg} / \mathrm{cm}^{2}$ pada umur 7 hari dan sebesar $48,53 \mathrm{~kg} / \mathrm{cm}^{2}$ pada umur 28 hari. Pada beton dengan penambhan serat eceng gondok sebesar 8\% memilkiki nilai kuat tekan rata-rata sebesar 33,03 $\mathrm{kg} / \mathrm{cm}^{2}$ pada umur 7 hari dan sebesar $47,18 \mathrm{~kg} / \mathrm{cm}^{2}$ pada umur 28 hari.

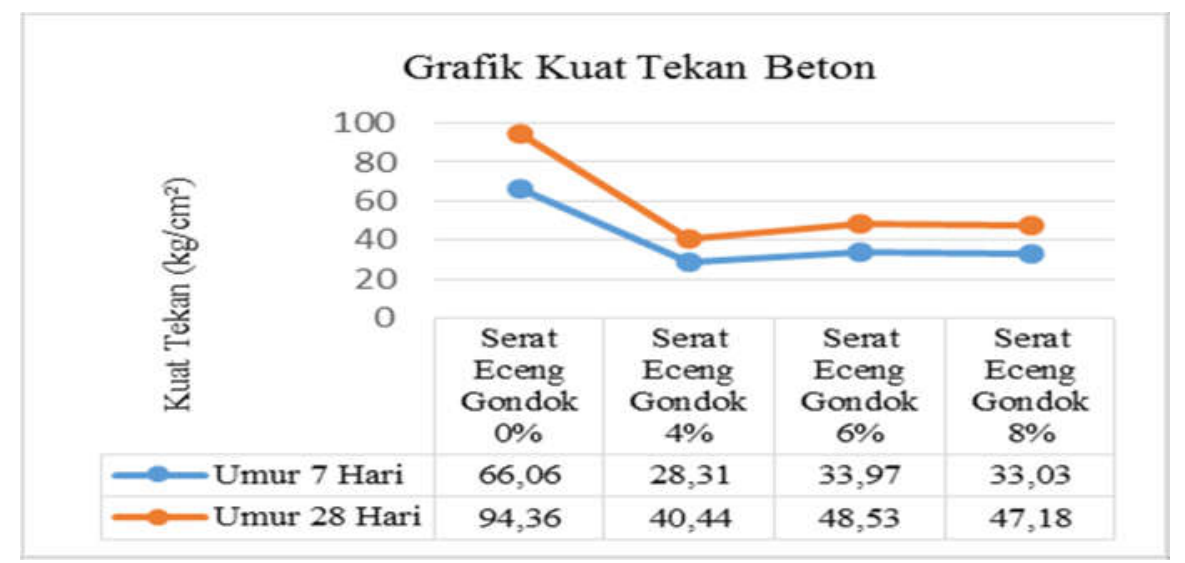

Gambar 1: Grafik Kuat Tekan Beton

Sumber : Hasil Penelitian, 2018 


\section{KESIMPULAN}

\subsection{Kesimpulan}

Dari data yang diperoleh dan dari analisa data yang telah dilakukan maka dapat diambil kesimpulan sebagai berikut :

1. Tahapan/ cara pembuatan serat eceng gondok yaitu: pengambilan eceng gondok dari sungai daerah deket dan dilakukan pemilahan batang dengan daun serta dilakukan pemotongan eceng gondok sebesar 3-5 cm dan kemudian pembersihan eceng gondok dengan air. Selanjutnya dilakukan penggilingan eceng gondok menjadi serat dan dilakukan pemerasan serta penyuwiran kemudian dilakukan penjemuran serat eceng gondok. Langkah terakhir serat eceng gondok yang kurang kering di oven dengan suhu $150^{\circ} \mathrm{C}$ dan dengan waktu pengovenan sesuai kebutuhan.

2. Dengan adanya penambahan serat eceng gondok dalam campuran beton dapat menurunkan kuat tekan. Hasil dari pengujian kuat tekan beton dengan penambahan serat eceng gondok sebesar $0 \%$ (Normal), $4 \%, 6 \%$, dan $8 \%$

\subsection{Saran}

Berdasarkan hasil penelitian, peneliti menyadari masih terdapat keterbatasan yang muncul, oleh karena itu hasil penelitian ini

belum dapat dikatakan sempurna, namun demikian diharapkan dapat memberikan kontribusi bagi mahasiswa lain dalam rangka pembelajaran. Terdapat beberapa hal yang dapat dilakukan lebih lanjut sebagai masukan yang mungkin dapat berguna bagi lembaga pendidikan perguruan tinggi ataupun mahasiwa, diantaranya yaitu :

1. Penentuan bahan semen, agregat halus, agregat kasar, dan bahan tambah yang digunakan dalam campuran beton harus benar-benar memenuhi syarat yang sudah di tetapkan.

2. Dalam proses penambahan air pada campuran beton harus sesuai mix design sehingga hasil uji slump yang didapatkan sesuai dengan standar yang sudah ditetapkan.

3. Untuk menjaga dan menetapkan kualitas mutu beton yang direncanakan, mahasiswa harus mampu menentukan kualitas bahan yang digunakan, mampu menghitung kebutuhan bahan yang digunakan, mampu menentukan timbangan yang benar-benar ketelitiannya sesuai standar, dan mampu mencampur bahan pembuat beton sesuai proporsi yang sudah ditetapkan, sehingga campuran beton benar-benar homogen dan menghasilkan beton yang baik.

\section{REFRENSI}

[1] ASTM,Annual Book of ASTM Standart Volume 04.02 "Concrete and Aggregates", 2001

[2] ASTM C 29-91, Standard Test Method for Bulk Density ("Unit Weight") 
and Voids Aggregates.

[3] ASTM C 33-01, Standart Specification For Concrete Agregate. Philadelphia

[4] ASTM,C39, Compresive Strength of Cylindrical Concrete Specimens, (2002). Annual Books of ASTM Standards, Philadelphia-USA.

[5] ASTM C 127, Standard Test Method for Density, Relative Density (Specific Gravity), and Absorbtion of Coarse Aggregate.

[6] ASTM C 128-78, Standard Test Method for Density, Relative Density (Specific Gravity), and Absorbtion of Fine Aggregate.

[7] ASTM C 187-86, Normal Consistency of Hydraulic Cement

[8] ASTM C 188-89, Density Test of Hydraulic Cement

[9] ASTM C 188 - 95, Standard Test Method for Density of Hydraulic Cement.

[10] ASTM C 191-92, Time of Setting of Hydraulic Cement by Vicat Needle

[11] ASTM C 566 - 89, Standard Test Method for Total Evaporable Moisture Content of Aggregate by Drying

[12] Badan Standarisasi Nasional. (2000). SNI 03-2834-2000, Tata Cara Pembuatan Rencana Campuran Beton Normal.

[13] Badan Standarisasi Nasional.. Hidayat, 2011. Pengaruh Penambahan Abu Sekam Padi Terhadap Kuat Tekan Beton K-225. Jurnal Aptek Edisi 2, Vol

[14] 3.Universitas Pasir Pengarai, Riau. Tjokodimuljo, Kardiyono. 2004. Tegnologi Beton. Nafiri, Yogyakarta

[15] Sugiyanto, G. (2017). Marshall test characteristics of asphalt concrete mixture with scrapped tire rubber as a fine aggregate. Jurnal Teknologi, 79(2). 